\title{
Genetic Relationship of Two Mutant Genes Which Producing Three Different Syndromes in the Mouse
}

\author{
Shigekatsu TSUJI ${ }^{1}$, Ann D. MacPIKE ${ }^{2}$, \\ Eisaku OHKOUCHI ${ }^{1}$ and Hans MEIER ${ }^{2}$ \\ Department of Physiology, Wakayama Medical College ${ }^{1}$, \\ Wakayama-shi, Japan and The Jackson Laboratory ${ }^{2}$, \\ Bar Harbor, Maine, U. S. A.
}

\begin{abstract}
We determined that leaner gene $(l a)$ is located in the linkage group XVIII and closely linked to $E s-1$, which is known to be located closely to tottering gene $(t g)$. Double heterozygote $(\mathrm{la} / \mathrm{tg})$ produced by mating between $\mathrm{la}$ heterozygote and $\mathrm{tg}$ heterozygote showed an intermediate syndrome between those seen in tottering $(\mathrm{tg} / \mathrm{tg})$ and leaner $(\mathrm{la} /$ la) mice. Both leaner and totterig mice showed neuromuscular disorders, but their clinical and pathological characteristics were different. Leaner mice were found to represent a socalled cerebellar mutant having the reduced size of cerebellum and severe cytoarchitectonic abnormalities with focal losses of Purkinje and granular layer cells. Tottering was, however, another mutation having epileptiform seizures, and it was characterized pathologically by cellular losses and shrinkage as well as vesiculations of cytoplasmic membranous structures in the cerebellum. The double heterozygote was shown to have both pathologic characteristics seen in each homozygote, and also showed shrinkage of Purkinje cells and vesiculaton of the endoplasmic reticulum and Golgi apparatus. These clinical and pathological findings supported the genetic data suggesting that $l a$ and $t g$ constitute an allele.
\end{abstract}

\section{二つの異なる症状を発現する神経系異常突然変異 形質の遺伝的相関性}

$$
\begin{aligned}
& \text { 辻 繁勝 }{ }^{1} \text { - A. D. マックパイク }{ }^{2} \cdot \text { 大河内英作 }^{1} \\
& \mathrm{H} \text { ・マイヤー2 }
\end{aligned}
$$

和歌山県立医科大学生理学教室 ${ }^{1}$

ジャクソン研究所 ${ }^{2}$

マウスに見出されている tottering ならびに leaner 形質はそれぞれ $t g$ 及び la という常染色体劣性遺伝子 によって発現される突然変異形質である。いづれも神経 一筋組織系の機能障害を発症するが, 互いに独立に見出 され, その臨床的病理学的症状が著しく相違するととか ら両者の間の遺伝的相関性に就いては考慮されていなか った。発現形質による分類では tottering 形質はいわゆ る epileptiform seizures のグループに属し，一方 leaner 形質は主として小脳に病理学的欠陥が認められるて とから cerebellar mutant のグループに入れられてい る[10］。又遺伝学的には tg遺伝子は第 XVIII 連鎖群に 属し，Es-1 遺伝子 (esterase-1 アイソザイムを発現す
る）と密接して存在するととが知られているが $[2], l a$ 遺伝子の連鎖群に就いてはこれまで不明であった。

われわれは種々の神経一筋組織突然変異体におけるエ ステラーゼアイソザイムの遺伝的調節を研究する過程 $[12,13]$ で tottering マウスと leaner マウスでの esterase-1 発現形質に違いが存在するととを見出し，こ の三遺伝子の間に連鎖が存在するととを報告している [15]。

本論文では $l a$ 遺伝子と $t g$ 遺伝子の相互関係につい て交配実験，発現症状の比較，および電子顕微鏡，光学 顕微鏡による脳組織の微細構造の変化等の面から検討を 加えた結果を報告する。 
Table 1 Test for allelism of $l a$ and $t g$ with reference to $E s-1$ phenotypes

\begin{tabular}{|c|c|c|c|c|c|c|c|c|c|}
\hline \multirow{2}{*}{\multicolumn{2}{|c|}{ Type of mating }} & \multirow{2}{*}{$\begin{array}{l}\text { Number of } \\
\text { matings }\end{array}$} & \multicolumn{3}{|c|}{ Normal } & \multicolumn{3}{|c|}{ Affected } & \multirow[b]{2}{*}{ Total } \\
\hline & & & $\frac{E s-1^{a}}{E s-1^{a}}$ & $\frac{E s-1^{a}}{E s-1^{b}}$ & $\frac{E s-1^{b}}{E s-1^{b}}$ & $\frac{E s-1^{a}}{E s-1^{a}}$ & $\frac{E s-1^{a}}{E s-1^{b}}$ & $\frac{E s-1^{b}}{E s-1^{b}}$ & \\
\hline 1. & $\frac{E s-1^{a}}{E s-1^{a}}+\frac{E s}{t a} \times \frac{E s-1^{b} t g}{E s-1^{b} t g}$ & 3 & 0 & 9 & 0 & 0 & 18 & 0 & 27 \\
\hline & $\frac{E s-1^{a}}{E s-1^{a}}+\underline{l a} \times \frac{E s-1^{a}+}{E s-1^{b}+t g}$ & 8 & 40 & 21 & 0 & 0 & 13 & 0 & 74 \\
\hline 3. & $\mathrm{~F}_{1}($ affected $) \times \frac{E s-1^{a}+}{E s-1^{b} t g}$ & 5 & 7 & 8 & 1 & 1 & 7 & 9 & 33 \\
\hline & $\mathrm{F}_{1}($ affected $) \times \frac{E s-1^{a}+}{E s-1^{a} l a}$ & 3 & 5 & 3 & 0 & 4 & 4 & 0 & I6 \\
\hline
\end{tabular}

\section{材料および方法}

$\mathrm{C} 57 \mathrm{BL} / 10 \mathrm{JGn}$ 系統で $t g$ 遺伝子と $E s-1^{b}$ 遺伝子が 同一染色体上に位置しているマウスを $t g$ 遺伝子用に使 用し, $E s-1^{b}$ を指標として検定を行った(ジャクソン研究 所 M. C. Green 博士の好意による)。la 遗伝子用には $E s-1^{a}$ 遺伝子を木モに有する $l a$ ヘテロ個体を用い $E s-1^{a}$ を指標として検定した。esterase-1 の表現型は尾部から 採血して得た血清を用いて, 通常の寒天電気泳動ザイモ グラム法で検定した[14]。

$t g$ 遺伝子と $l a$ 遣伝子の対立性検定には次の組合せで 交配実験を行った。

(1) $E s-1^{a}$ をホモに la をへテロに保有する雌と Es$1^{b}$ および $t g$ をホモに有する雄とを交配させる。

(2) $E s-1^{a}$ と $E s-1^{b}$ を有し $t g$ をへテロに保持する 雌と Es-1 ${ }^{a}$ を木モに la をへテロに有する雄とを交配 させる。

以上の交配により, むし $E s-1, t g, l a$ の三遺伝子が 全て密接して存在するとすれば三重異型接合体の仔マウ スが交配(1)から $1 / 2$ の率で, 又交配(2)からは $1 / 4$ の率で発 現するはずである。さらに，むし $l a$ と $t g$ が対立遺伝子 であれば，乙れら三重異型接合個体は神経系異常の形質 を発症するはずである。

光学顕微鏡用切片は取出した脳標本を通常の $10 \%$ 中性 ホルマリンで固定し, パラフィン切片作製後, ヘマトキ シリン・エオシン単独染色及びラキソール・ファストブ ルーとの二重染色 [5] を行い神経細胞, 䯣鞘の同定に 用いた。

電子顕微鏡による検査は病変が主として小脳中心に見 られるととから生後18日乃至20日の $l a / l a, l a /+,+1$ 十各同腹マウス, 生後 4 ケ月の $\mathrm{la} / \mathrm{tg}$ マウス, 及び生 後 3 ケ月の同腹 $t g / t g, t g /+,+/+$ マウスの小脳をそ れぞれ使用た $[6] 。$
標本作製は，まずマウスを $\mathrm{Co}_{2}$ で麻醉後直ちに $4.5 \%$ グルタールアルデヒド，アルカリ燐酸縓衝液 $(\mathrm{pH} 7.4)$ で灌流し $[9]$, 取り出した脳を同じ緩衝液に $0.2 \mathrm{M}$ サッ カローズを加えた溶液で一夜洗涤する。約 $1 \mathrm{~mm}^{3}$ のブロ ックを小脳の後葉虫部から切出し, ベロナール・酢酸楥 衝液（pH 7.4）に $1 \% \mathrm{OsO}_{4}$ を入れた溶液中で氷冷で 60分間静置した後室温に戻す $[7]$ 。固定後アルコール． シリーズ及びプロピレンオキサイドで脱水し， Maraglass655[11] 或いは ACM Durcupan (Eluka) で包埋 し, Porter-Blum MT-1 ウルトラ・ミクロトームで切 片を作った。

成

績

交配実験の結果は Table 1 のでとくである。血清 esterase-1 表現型を指標として検定を行い，その区分中 での疾病の発現を調べると，交配(1)では仔マウスに Es$1^{a} / E s-1^{b}$ 型のみが発現し27頭のうち18頭 (67\%) が行動 異常を示した (Fig. 1)。残りの 9 頭は外見的に 全く正 常であった。との結果から $t g$ と $l a$ 両遺伝子は少なく とも相補的に働いて疾病を発現させ得るととが確められ たわけである。さらに交配(2)では $E s-1^{a} / E s-1^{a}$ と $E s-1^{a}$ $/ E s-1^{b}$ の二型のみが発現し， $E s-1^{b} / E s-1^{b}$ 個体は見ら れなかった。

$E s-1^{a} / E s-1^{a}$ 個体は全て正常であったが $E s-1^{a} / E s-1^{b}$ 個体34頭のうち13頭（38\%）に行動異常が認められた。 これは $\lg$ とlaが対立遺伝子である場合の出現率を充分に 満足させている。そてで次に行動異常を発現した $\mathrm{F}_{1}$ 雄、 ウスをそれぞれのへテロ親にもどし交配させた所（交配 (3)及交配(4)), 交配 (3) で 2 頭の組換え型が発現した。そ のうち 1 頭は $E s-1^{b} \cdot t g$ と $E s-1^{a} \cdot l a$ の間に組換えが 起った $\mathrm{la} / \mathrm{tg}$ 個体で，他は $E s-1^{a}+$ と $E s-1^{b} \cdot \operatorname{tg}$ と の間に起った $t g /+$ ヘテロ個体であった。交配(1) 及び (2)での行動異常マゥスの発現率及び交配(3)及び(4)での分 


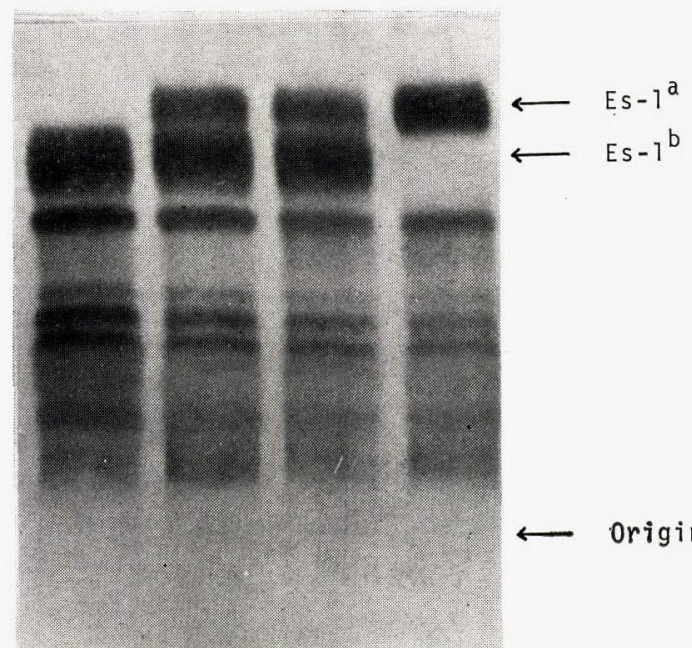

(a)

(d)
Fig. 1 An agar-gel zymogram of serum esterase; alpha-naphthyl butyrate was used as substrate.

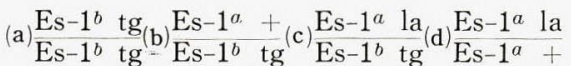

Channels (a), (b) and (d) are of the parental types, and channel (c) represents double heterozygote of $l a$ and $t g$ with clinically abnormal behavior.

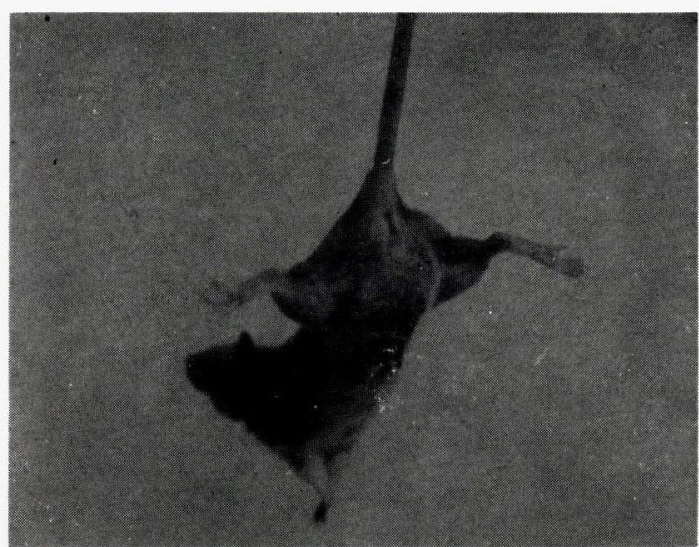

Fig. 2 An la/tg mouse, age 10 weeks, assuming characteristic posture of stiffening of hind limbs and extending them sideways when lifted by the tail.

離比加ら考えて $\operatorname{tg}$ と $l a$ は対立遺伝子であり, 且第 XVIII 連鎖群に属する $E s-1$ 遺伝子と密接した座位に存 在するととは明らかである。

$\mathrm{la} / \mathrm{tg}$ マウスの外見的特徴：行動異常が発現するのは 生後15乃至17日である。運動失調, 硬直痤攣状態及び運 動遅滞がその主な症状であるが，初期症状としてはまず
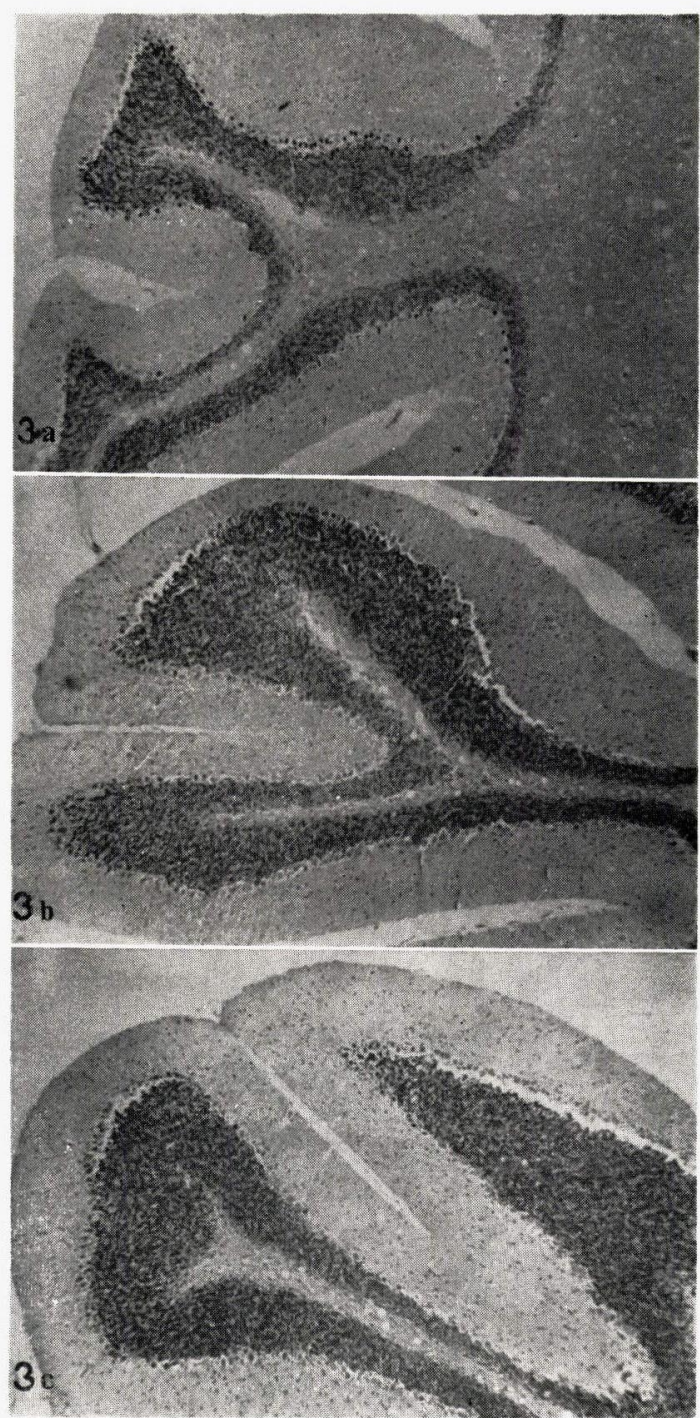

Fig. 3 Photomicrograph of cerebellar lobe of mice with three different syndromes. In leaner cerebellum, there is shrinkage of Purkinje cells with focal losses and the granular layer consists mostly of Golgi type II cells. (3, a) The granular layer of tottering contains both small dense type cells and large pale Golgi type II cells $(3, \mathrm{~b})$. The aberration of heterozygote $(\mathrm{la} / \mathrm{tg})$ cerebellum resembles quantitatively those found in tottering but considerably more severe $(3, c)$.

ゆらゆら歩き, 断続的な痤攣発作等が起り, 生後 4 週間 頃になるとすべてのマウスに完全な痙挲状態が発見し， その後, この症状はマウスの生涯を通じて続く。痤卛は 突然発生し, 途中小康状態があるが歩行を始めると再び 発作が起り，この繰返しが一時間程続く。 
痙卛発作のない時でも常にゆらゆら歩き, 尾を持って 持上げると後肢を硬直させ八の字形に両側に広げる

(Fig. 2)。大部分のマウスが乳離れ期迄, その不自由さ に打勝って生残り，成体になってもやせて小型ではある が正常マウスとほぼ同じ寿命を全うする。成体ではいわ ゆる runt disease 様の外見を呈し, 生後 1 ケ月での体 重は $7.5 \pm 0.1 \mathrm{~g}$ (10頭の平均) と正常同腹マウスの体重 $12.7 \pm 0.2 \mathrm{~g}$ (10頭の平均) のほぼ半分程度である。生殖 は可能であるが雌雄共にやや困難である。

組織学的所見：leaner マウスでは正常対照と比較し て, 小脳がいちじるしく小型になっていることが特徴的 であるが, 組織学的変化は Fig. 3a のごとく顆粒層が 著しく萎縮し, 細胞数が減少して居り, 特にプルキンエ 細胞が極くまばらになっている状態が認められる。一方 tottering マウスの方は小脳の大きさ，その他脳全体の 外見は正常と変りなく顆粒層の細胞数屯正常である。わ ずかにプルキンエ細胞の数が減少しまばらに分布してい るのが認められる (Fig. 3b)。

これに対して $l a / t g$ マウスの小脳ではやはりプルキ ンエ細胞が減少しているのは認められるが，顆粒層の細 胞数は leaner 程極端に減少してはいない。即ち $\mathrm{la} / \mathrm{tg}$ マウスの組織学的変化は全体として leaner と tottering の中間的状態を示しているといえる (Fig. 3c)。
微細構造所見: Fig. 4 は正常対照, Fig 5, 6, 7 はそ れぞれ tottering, leaner 抢よび la/tg マウスの小脳虫 部の電顕像である。3 形質共に顆粒層中の細胞数が減少 し, プルキンエ細胞の萎縮が認められるが, 特にtottering マウスではプルキンエ細胞の萎縮がいちじるしく, 核は引延ばされて不整形になり核膜は凹凸になり所々に 陥入部が生じている。さらに粗面小胞体は空胞化し，リ ボゾームを消失しているが, わずかに残存しているリボ ゾームはしばしば群をなしポリゾームを形成し，ときに ボール型をしたミエリン様構造が形成されているのが認 められた。神経束には変化なく,グリア細胞も殆んよ゙無 変化であった（Fig 5)。leaner マウスでは細胞構造の 変化が 3 形質のうちで最も激しく, プルキンエ紐胞は萎 縮し, 租面小胞体は空胞化し, 多くのミトコンドリアの クリステは消失している。また, 多数のミエリン様残存 構造が認められた。leaner 形質で特徵的なのはプルキ ンエ細胞の著しい萎縮と欠損であるが, 同時にゴルジ II 型細胞にも強い変化が認められ, 細胞膜及び他の膜構造 物であるミトコンドリア, 租面小胞体等が破損し基質中 に四散しているの認められる。軸索の多くが胞状構造を 失い,わずかにミトコンドリア等の残存物を含んでいる が対照的に内部の線維はほとんど無変化である (Fig. 6)。 $\mathrm{la} / \mathrm{tg}$ マウスの小脳組織像は leaner, tottering 両形質

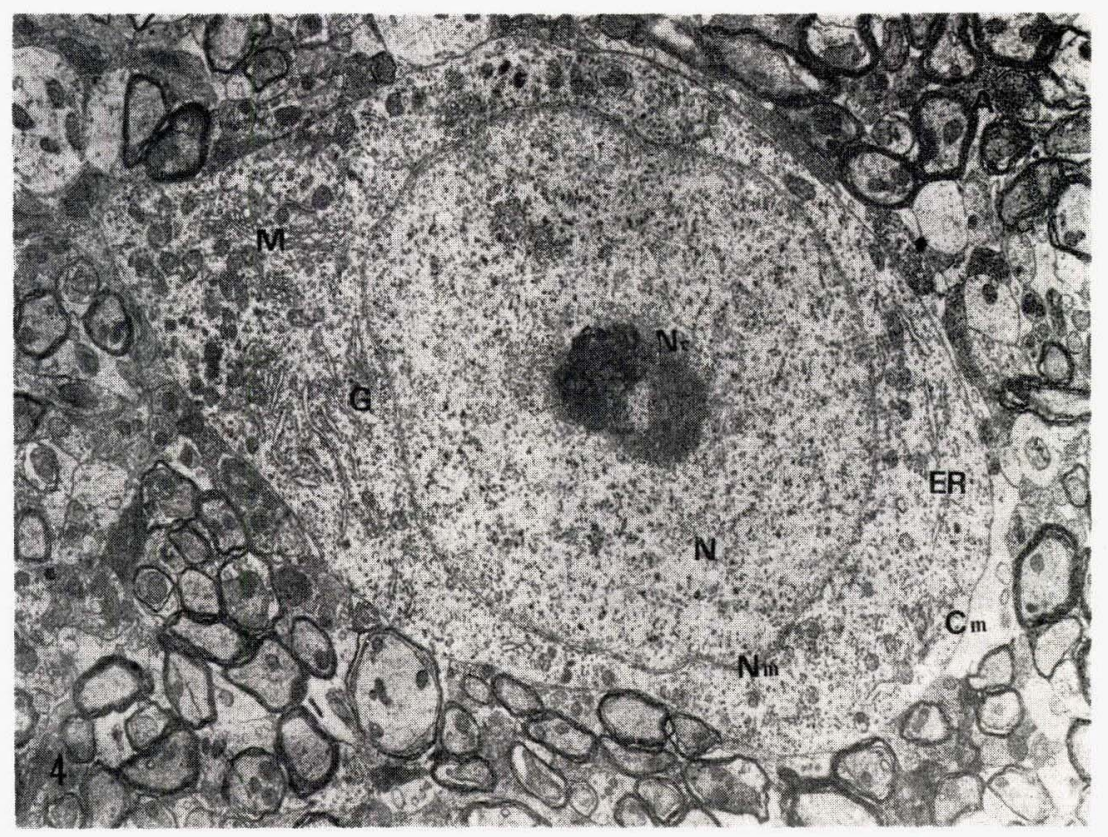

Fig 4 Control mouse $(+/-$ or $+/+), 20$ days old. Cerebellar Golgi type II cell surrounded by netwark of axons $(\times 22,000)$. There are neither real nor artifactual changes in structural cell components. The cell components are identfied as follows : A, axons ; $\mathrm{Cm}$, cell membrane ; $\mathrm{ER}$, endoplamic reticulum ; $\mathrm{G}$, Golgi apparatus ; M, myelin ; N, nucleus ; Nc, nucleolus ; Nm, nuclear membrane. 


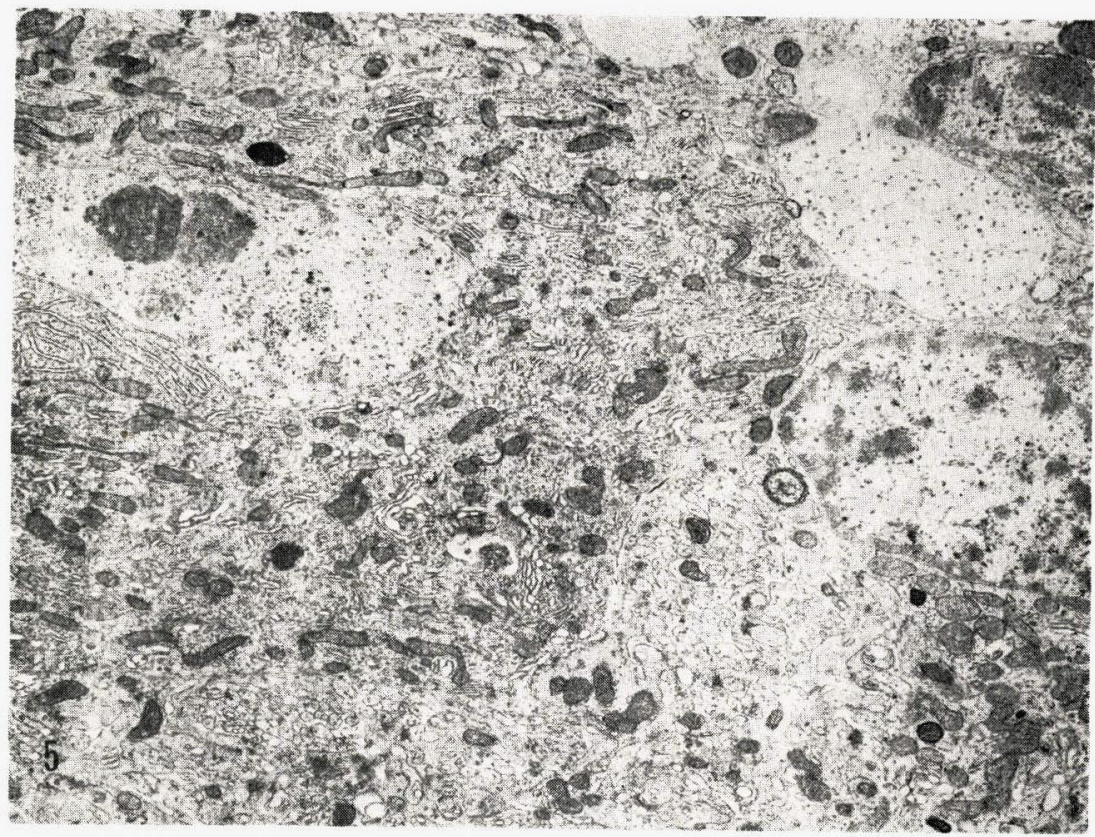

Fig. 5 Tottering mouse, 3 month old. Purkinje cell with surroudig neuropile. The cell is shrunken, and nuclei elongated and irregu-larly indented $(\times 29,000)$.

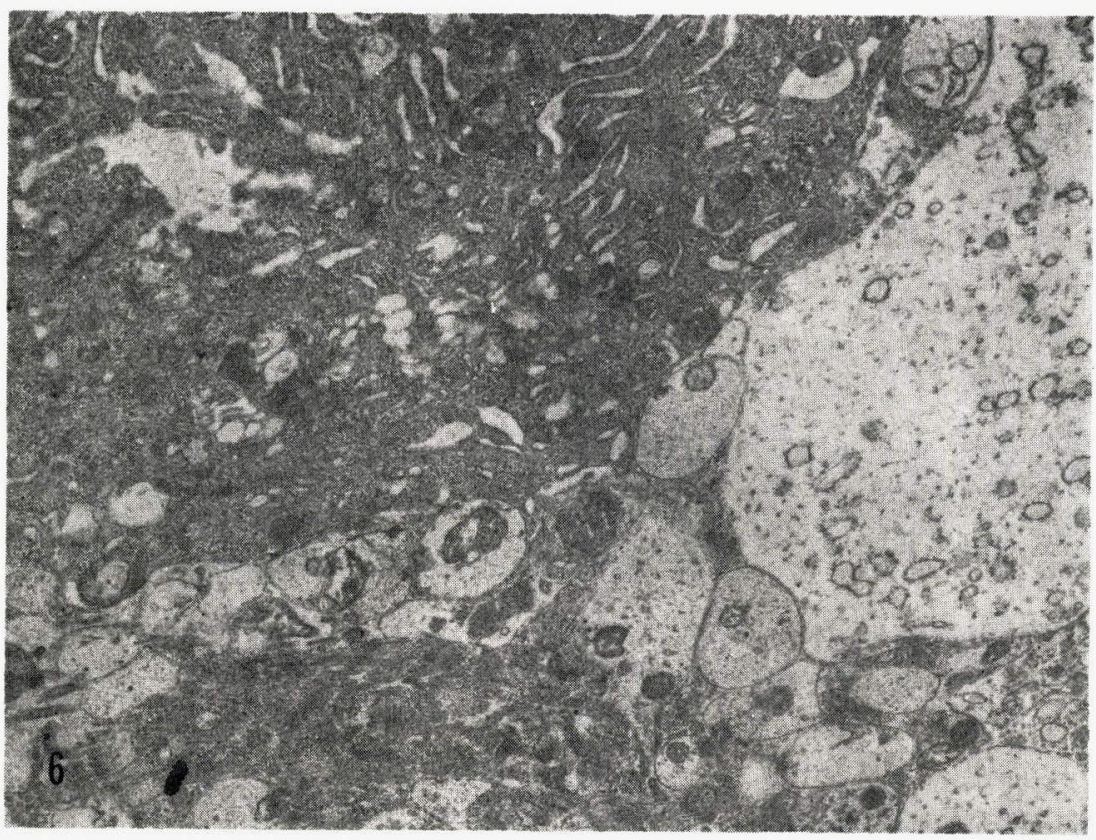

Fig. 6 Leaner mouse, 20 days old. Purkingje cell cytplasm reveals vacuolation and vesiculation of endoplasmic reticulum, mitochondrial swelling and degenerative myelin figures $(\times 13,500)$. 
Table. 2 Comparison of histological changes in cerebellum of the mice with the three syndromes

\begin{tabular}{|c|c|c|c|}
\hline Mutation & Molecular layer & Granular layer & Purkinje cell layer \\
\hline $\begin{array}{l}\text { Leaner } \\
\qquad(l a / l a)\end{array}$ & $\begin{array}{l}\text { Absence of nerve cells } \\
\text { noted in this layer. } \\
\text { Nerves myelinated normally. }\end{array}$ & $\begin{array}{l}\text { Excess number of } \\
\text { Golgi II cells and } \\
\text { evidence of leakage of } \\
\text { cytoplasm. }\end{array}$ & $\begin{array}{l}\text { P-cells scattered and do not } \\
\text { form layer. Loss of ultrast- } \\
\text { ructure. }\end{array}$ \\
\hline $\begin{array}{r}\text { Tottering } \\
(\mathrm{tg} / \mathrm{tg})\end{array}$ & $\begin{array}{l}\text { Several Golgi II cells show } \\
\text { degeneration as the other } \\
\text { cells of this layer. }\end{array}$ & $\begin{array}{l}\text { Cells are in normal } \\
\text { numbers but are some- } \\
\text { what shrunken. }\end{array}$ & $\begin{array}{l}\text { Loss of ribosomes from the } \\
\text { endoplasmic reticulum. } \\
\text { Shrinkage of nuclear and } \\
\text { cytoplamic material. }\end{array}$ \\
\hline $\begin{array}{l}\text { Leaner-Totter- } \\
\text { ing }(\mathrm{la} / \mathrm{tg})\end{array}$ & $\begin{array}{l}\text { Very Similar to the } \\
\text { Tottering mutant. }\end{array}$ & $\begin{array}{l}\text { Some loss of cells and } \\
\text { those remaining are seve- } \\
\text { rely shrunken, especially } \\
\text { Golgi II cells. } \\
\text { Also evidence of leakage. }\end{array}$ & $\begin{array}{l}\text { Loss of ultrastruture especially } \\
\text { in endoplasmic reticulum. } \\
\text { Both ER and Golgi apparatus } \\
\text { are severely vacuolated. }\end{array}$ \\
\hline
\end{tabular}

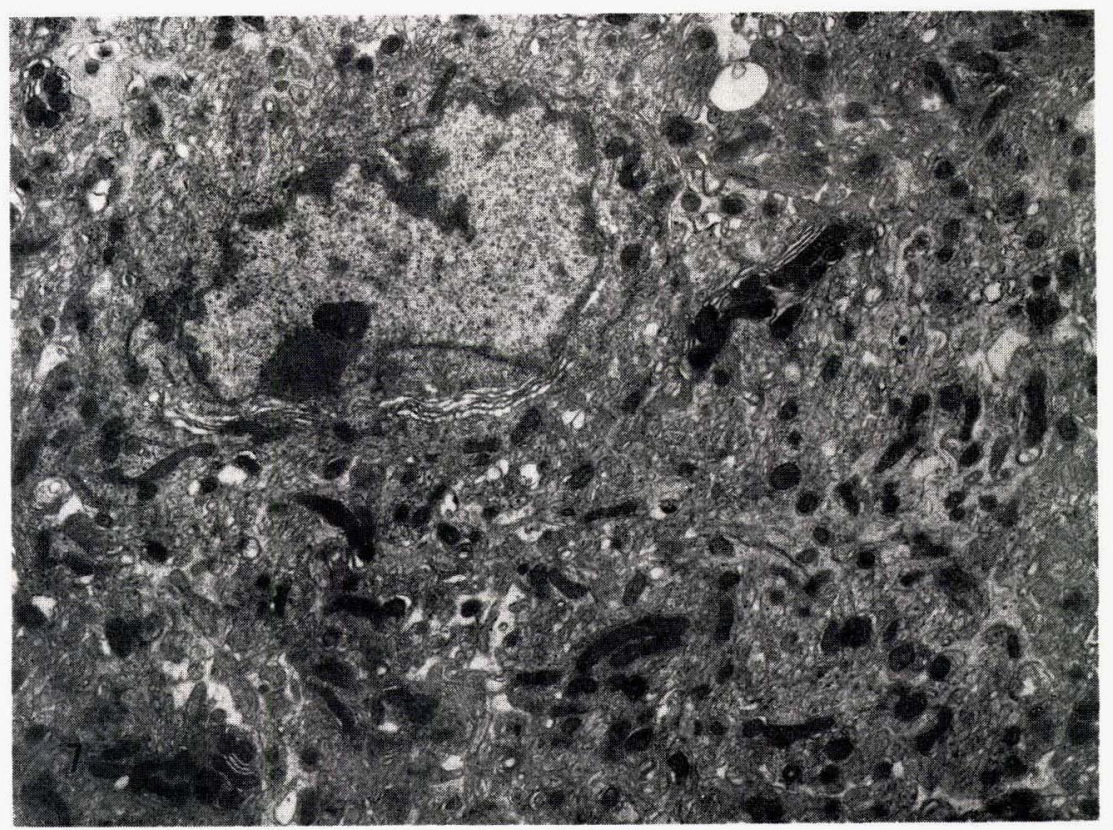

Fig. 7 Heterozygous mouse $(\mathrm{la} / \mathrm{tg}), 4$ month old. Granular cell. Some mitochondria are severely swollen and elongated, and others are shrunken. They undergo degenerative changes including loss of cristae $(\times 29,000)$.

の特徵をあわせた変化を示している。特にプルキンエ細 胞の萎縮, 小胞体及びゴルヂ装置の空胞化が目立ってい るが, $l a / t g$ マウスには leaner マウスで見られる様な 膜構造の欠損は認められなかった (Fig. 7)。

Table. 2 は小脳微細構造の変化を 3 形質それぞれの
特徴としてまとめたあのである。

これら 3 形質に共通して認められるミトコンドリア, 小胞体, 及び細胞全体の萎縮或いは膨潤等の変化は, $\operatorname{tg} /+, l a /+,+1+$ 等の対照マウスではまったく認め られなかった。 


\section{考}

\section{察}

$l a$ 遺伝子と $t g$ 遺伝子の二重異型接合体での症状発現 時期は leaner マウスと同じく生後15日頃であり, 症状 は tottering マウスのそれに類似してはいるが, やや重 症である[3]。 tottering マウスの症状は生後 $3 \sim 4$ 週 間で発現し, 発作時を除いてその行動は比較的稳かで, ほほ正常に発育し寿命む正常である。てれに対して leaner マウスは生後約 3 週間ですべて死亡するので系統 維持のためにはへテロ個体同志の交配が必要である。小 脳は小型で顆粒層の菱縮, プルキンエ細胞内構造物のい ちじるしい欠損, グリア細胞の增殖等が認められる[10]。 一方 $l a / t g$ 二重異型接合体はやせて小型ではあるが組織 学的に leaner より軽症の変化が認められる程度で, 数 ケ月にわたって生存し, 生殖は困難ではあるが可能であ る。

以上のでとく症状及び組織学的変化をそれぞれのマウ スについて比較すると $l a$ 遺伝子と $t g$ 遺伝子が形質発現 に関して相補的に㗢いているととは明らかである。すな わち両突然変異は同一遺伝子座内において異った部分に 欠損を有し, 互の正常部分がある程度てれを補っている あのと考えることができる [1]。さらに推論すれば la と tg は同一のオペロン中の異った部分に発生した突然 変異であり, $l a$ の方が $t g$ よりあ欠損部分が大きく且つ オペレーター遺伝子に近接した部分に存在するため症状 がより重く現われ， $l a / t g$ では $t g$ 遺伝子側の正常部分 からの選択模写によって la 遺伝子の欠損がある程度補 正されるので leaner マウスに比較して 軽度な症状を示 すむのと推測するととができる[4]。勿論 $l a$ と $\operatorname{tg}$ の 表現型の違いはオペレーター遺伝子自体の違いであるか あしれないし，また， leaner が致死なのは，la が隣接 した致死座位の欠損をあ含んでいるためである可能性を 否定することはできないが, $l a / t g$ 二重異型接合体の症 状が leaner よりもむしろ tottering の症状に類似して いることは両遺伝子の欠損部分のうち, 互にオーバーラ ップしている部分によって発現されるためであると仮定 すると説明しやすくなる。

交配実験の結果は期待値によく一致し, 両遺伝子が対 立遺伝子であるととを充分示唆しているが，乙の結果の みでは両遺伝子が非常に近接した別個の独立した遺伝子, 即ち疑似対立遺伝子である可能性を完全に否定すること はできないし，そのためには膨大な数の交配実験を行 い, シス配置のへテロ個体が存在し得ないととを統計的 に確める必要があるが[ 8 ], 一方電子顕微鏡による検索 結果は, 外見的症状の観察と合せて, la遺伝子と $t g$ 遺伝 子が対立遺伝子であるととを強く支持している。すなわ
ち, 3 形質とあにプルキンエ細胞及び顆粒層中の細胞群 が減少または欠失しているが， totteringマウスでは顆粒 層中に 2 つのタイプの細胞群が存在するのに対して $l a /$ $\operatorname{tg}$ マウスにはゴルジ II 型細胞のみが存在する。また小胞 体の空胞化と細片化は 3 形質に共通な現象ではあるが, $l a / t g$ が最あ重症である。膜の破損による細胞内容物の 基質への流出は leaner マウスのみに起り，ポリリボゾ 一ムの形成は tottering マウスに特徴的な現象である。

以上のような電子顕微鏡所見から, la $/ \mathrm{tg}$ 形質は明ら かに leaner 形質と tottering 形質の中間的特徴を多く 有しており, la と $\operatorname{tg}$ が対立遺伝子であると考えるのは 妥当である。また leaner マウスに認められる膜構造物 の破損という現象は最む重症な変化であり，このととが ほとんどの leaner マウスが幼児期に死亡する原因のひ とつとなっているものと推測される。

\section{要約}

$l a$ 遺子が第 XVIII 連鎖群に属しているととを見出し た[15]。さらに $E s-1$ 遺伝子と密接して存在する事が知 られている $t g$ 遺伝子 $[14]$ 乙 $l a$ 遺伝子が複対立遺伝子 の関係にあることが確められた。

両遗伝子の二重異型接合体 $(\mathrm{la} / \mathrm{tg})$ は leaner マウス $(l a / l a)$ と tottering マウス $(t g / t g)$ の中間的な症状 を示すが後者により強く類似している。症状の発現は leaner とほぼ同じく, 生後約 2 週間で tottering より早 い。また組織学的所見も外見症状とほぼ平行していた。 すなわち leaner では顆粒層での細胞数の著しい減少, プルキンエ細胞の欠失, 膜の破損に伴う原形質の流出之 いう強い小脳欠陥が見られるが, tottering と la/tg マ ウスでは細胞数の減少と萎縮及び細胞内膜構造物の空胞 化という特徽が認められる。一方 tottering ではこの症 状がゆるやかに長期間にわたって発現するので, 生後 4 ケ月であ顆粒層に 2 タイプの細胞が存在する。

一方 la/tg マゥスでは leaner とほぼ同じ生後 2 週間 で症状発現が見られるが, その進行程度は leaner より あ遅い。以上の組織学的観察加ち $l a$ 遺伝子と $t g$ 遺 伝子が対立関係にあるととが強く支持された。

\section{文献}

[1] Benzer, S. (1957). The elementary units of hereditary. In The chemical basis of heredity 70-93, Ed. W. D. McElroy and H. B. Glass, Johns Hopkins Press, Baltimore.

[2] Green, M. C. (1965). Mutant genes and linkages. In Biology of the laboratory mouse. 
2nd Ed. 87-150, Ed. E. L. Green, McGrawHill, New York.

[ 3 ] Green, M. C. and Sidman, R. L. (1962). Tottering, a neuromuscular mutation in the mouse and its linkage with oligosyndactylism. J. Hered. 53, 233-237.

[4] Jacob, F. and Monod, J. (1961). On the regulation of gene activity. Cold Spring Harbar Symp. on Quant. Biol. 26, 193-211.

[5] Margolis, G. and Pickell, J. P. (1956). New applications of the luxol fast blue myelin-stain. Lab. Invest. 5, 459-474.

[6] Meier, H. and MacPike, A. D. (1971).

Three syndromes produced by two mutant genes in the mouse. J. Hered. 62 (5), 297302.

[7] Palade. G. E. (1952). A study of fixation for electron microscopy. J. Exptl. Med. 95, $258-297$.

[8] Phillips, R. J. S. (1966). A cis-trans position effect at the A locus of the house mouse. Genetics 54, 485-495.

[9] Sabatini, D. D., Bensch, K. and Barrnet, R. J. (1963). Cytochemistry and electron micros- copy : The preservation of cellular ultrastructure and enzymatic activity by aldehyde fixation. J. Cell Biol. 17, 19-58.

[10] Sidman, R. L., Green, M. C. and Appel, S. H. (1965). Catalog of the neurological mutants of the meuse. Harvard Univ. Press, Cambridge Mass.

[11] Spurlock, B. O., Kattinean, V. C. and Freeman, J. A. (1963). Technical modifications in maraglass embedding. J. Cell Biol. 17, 203 -207 .

[12] Tsuji, S. and Meier, H. (1970). Esterase alterations in the liver of dystrophic mice. Experientia 26, 547-548.

[13] Tsuji, S. and Meier, H. (1971). Liver seterase abnormalities in hereditary neurological diseases of mice. Experientia 27, 258-259.

[14] Tsuji, S. and Meier, H. (1969). Linkage of serum esterase and tottering in the mouse. J. Hered. 60, 221-222.

[15] Tsuji, S. and Meier, H. (1971). Evidence for allelism of leaner and tottering in the mouse. Genet. Res., Camb. 17, 83-88. 